традиционным типом правосознания, базирующимся на внутрисоциальном способе правообразования; 4) религиозно-доктринального - получившего наибольшее распространение в теократических государствах и основанном, на тезисе о том, что право носит божественный характер [3, с. 43].

В заключении необходимо отметить, что применение сравнительно-правового метода в изучении правовых систем различных стран (в частности законодательных актов), связано с все более укрепляющимися отношениями сотрудничества мирового сообщества, развитием международных экономических, политических, социальных и культурных связей, а также с усилением информационных, интегративных и глобализационных процессов.

$$
\text { *** }
$$

1. Власов В.И. Сравнительное правоведение: учебное пособие / В.И. Власов, Г.Б. Власова, С.В. Денисенко. - М.: КНОРУС, 2014. - 248 с.

2. Давид Р., Жоффре-Спинози К. Основные правовые системы современности: Пер. с фр. В.А. Туманова. - М.: Международные отношения, 1999. - 400 с.

3. Захарова М.В. Сравнительное правоведение: вопросы теории и практики: монография. - М.: Проспект, 2012. - 160 с.

4. Малько А.В. Сравнительное правоведение / А.В. Малько, А.Ю. Саломатин. - М.: Норма: ИНФРАM, 2010. - $352 \mathrm{c}$.

5. Марченко М.Н. Курс сравнительного правоведения. - М.: ООО «Городец-издат», 2002. - 1068 с.

6. Осакве К. Сравнительное правоведение в схемах: Общая и Особенная части: Учебно-практ. пособие. - 2-е изд., перераб. и доп. - М.: Дело, 2002. - 464 с.

7. Рассказов Л.П. Основы юридической науки. - М.:А-проджект, 2017. - 313 с.

8. Саидов А.Х. Сравнительное правоведение / А.Х. Саидов. - М.: Норма: ИНФРА-М, 2011. -368 с.

9. Синюков В.Н. Российская правовая система. Введение в общую теорию: монография / В.Н. Синюков. - 2-е изд., доп. - М.: Норма: ИНФРА-М, 2016. - 672 с.

10. Тихомиров Ю.А. Курс сравнительного правоведения. - М.: Издательство НОРМА, 1996. - 432 с.

11. Цвайгкрт К., Кётц Х. Введение в сравнительное правоведение в сфере частного права: В 2-х тт. Том I. Основы: Пер. с нем. - М.: Международные отношения, 2000. - 480 с.

12. Чиркин В.Е. Основы сравнительного правоведения / В.Е. Чиркин. - М.: НОУ ВПО «МПСУ»; Воронеж: МОДЭК, 2014. - 392 с.

13. Юридический энциклопедический словарь / под ред. А.В. Малько. - 2-е изд. - М.: Проспект, 2017. $-1136 \mathrm{c}$.

\title{
Уханов А.Д. Понятие и функции правового менталитетат
}

НИУ «Высшая школа экономики» (Россия, Москва)

doi:10.18411/spc-20-01-2018-08

idsp: 000001:spc-20-01-2018-08

Понятие правовой менталитет является достаточно новым в отечественной юридической науке и редко используется ею, однако постепенно «завоёвывает» всё большее признание. При этом, учитывая новизну, сопровождающуюся теоретикометодологическим оформлением понятия, наполнения его устойчивым смыслом, возникает определённая путаница. Правовой менталитет может отождествляться с правосознанием, правовой культурой, ценностными структурами правовой системы и другими широкими и слабо конвенциональными понятиями, призванными пояснить «туманные» пласты правовой реальности. В связи с этим возникает необходимость обратиться к источникам, специально посвященным проблеме правовой ментальности, при том в её концептуальном измерении.

Вообще правовой менталитет выступает явлением, связывающим национальную культуру с правом. Так в литературе имеется следующая дефиниция правового менталитета, под ним предлагается понимать «совокупностью (системой) правовых архетипов и представлений, устойчивых, привычных образов, форм и стиля 
юридического мышления, которые в разных социумах, этносах, типах цивилизаций и т.п. имеют собственное содержание, различным образом сочетаются, но всегда лежат в основе восприятия компонентов национальной государственности (юридических и политических институтов, национальных и конфессиональных отношений и др.), определяют специфику правового поведения индивида, тех или иных социальных и профессиональных групп, государственных органов и должностных лиц» [1].

Правовой менталитет является сложной системой и включает в себя следующие структурные элементы: политико-правовая парадигма, стиль юридического мышления, тип социально-правового и предправового поведения. Так политико-правовая парадигма образует исходный уровень других компонентов правового менталитета, схватывает, фиксирует характер (специфику) отношений личности, права и государства в рамках того или иного типа цивилизации или этноса. Стиль правового мышления включает когнитивные установки, обусловливающие понимание того, что такое право, закон, справедливость, правосудие, государственная власть и способы принуждения индивидов и их групп, правомерное и неправомерное поведение. И наконец, тип предправового поведения наличинствует, прежде всего, как продукт самоорганизации и саморазвития национального бытия, нормы, запреты, представления о допустимых, недопустимых и обязательных видах и формах индивидуальной и коллективной активности. На «тотальный» характер правового менталитета указывает тот фактор, что он «как сложное явление отражается во всех элементах структуры правосознания и раскрывается в специфике правопонимания, правочувствования, правовидения» [2].

Обобщая все вышесказанное, можно говорить о нескольких основных функциях правового менталитета, обусловленных его природой, ролью и местом в национальной правовой и политической жизни [1]: 1) познавательно-преобразовательная, связанная с накоплением знаний о специфике правового пространства и с деятельность по его преобразованию; 2) праворегулятивная и интеграционная направлены на обеспечение устойчивого, отлаженного правового уклада общества в целом, социальных групп (классов, страт), семей, отдельных индивидов, регулирование их взаимоотношений; 3) оценочная, проявляющаяся в разнообразных фактах, отражающихся в сознании и поведении индивидов и их групп, связанных с оценкой, соответствующим ей эмоциональным отношением субъектов к тем или иным элементам правовой и политической жизни; 4) кумулятивно-охранительная, предполагающая постоянное прибавление (правда, за весьма длительный период исторического времени), увеличение этноправовой информации на уровне архитектонических структур (в неразрывной взаимосвязи рациональных и иррациональных компонентов) при сохранении (для последующих поколений) уже имеющейся; 5) социализирующая функция охватывает область общей индивидуальной социализации и инкультурации как приобщение индивида к национальному социально-правовому опыту; 6) прогностическая (проспективная) функция включает анализ тенденций, перспектив развития национальной правовой (политической) системы.

Работа выполнена при финансовой поддержке гранта РФФИ № 17-33-00034 (a1)

$$
* * *
$$

1. Мордовцев А. Ю., Попов В. В. Российский правовой менталитет. Ростов-н/Дону. 2007.

2. Поляков А.В. Общая теория права. СПб., 2001. 